to call ourselves Black feminists was in itself a collective affirmation of the need to construct a feminism that spoke to gender, class and race, growing out of our experiences and because of our connections to our Black communities and cultures.

Bell hooks makes the point that the feminist movement in the States was one which automatically excluded a great many people. And she points to its symbolic gestures at the beginning of the movement - braburning, protesting the Miss America Pageant-as examples of its flawed class analysis.

But she asks the question: 'What if our symbolic gestures were women at a factory protesting against working conditions? This would have a far more radical impact on our consciousness than the image of people burning a bra.'

I couldn't agree more. That is why Black feminists in Britain identified with and supported the women workers during the Grunwick strike of 1977; why we fought against sin bins and disruptive units for Black children and why we successfully fought to end virginity tests for Asian women at British ports of entry.

We are in our communities and of our communities; and just as those communities must come to terms with their hostility towards Black women and men who are lesbian or gay, so must it accept its sisters who are feminist, who are saying, you must realize the sexism which exists and work to eradicate it, as you work to eradicate racism and class division.

The value we place on naming ourselves demands nothing less.

\section{Melba Wilson}

\section{Victorian Writing and Working Women: The Other Side of Silence}

\author{
Julia Swindells \\ Polity: Oxford 1986 \\ $£ 7.95 \mathrm{Pbk}, 0745600727$ \\ $£ 25.00 \mathrm{Hbk}, 0745600719$
}

Julia Swindells book at once debunks the myth of feminism as humourless and academic writing as forbiddingly 'difficult'. Even the cover functions as a visual pun; the middle-class woman who reads face to face with the working-class woman who is read about, bringing the two together, equally stylized in the male representation. This points to one of the book's central arguments, the relation of 'literariness' to the moral in the construction of subjectivities. Although Swindells is reluctant to define 'the literary', it connotes in general terms those symbolization processes which, in the nineteenth century, get enshrined in the novel as the genre most widely read and canonized in the production business of high culture. Thus in Swindells account of the correspondence between Mary Smith and Jane Carlyle, two women whose different position in relation to the 'literary' and to class is similarly marked, there is involved (for all the women concerned) a process of negotiating predetermined categories of 'appropriate' writing.

It is no accident that I begin with an illustration from the second half of the book, where the shift occurs from canonical fiction to the writings of working women autobiographers. It is part of the logic of the book that its preliminary arguments about the class relations of writing should begin to tell at this later stage. In Dickens'Little Dorrit one version of a Victorian maidservant is represented, but the relation between domestic service and writing is far more acutely and painfully realized in the account of a working woman autobiographer such as Elizabeth Ham. In George Eliot's Adam Bede 
one version of a working woman's experience of oppression is represented through Hetty Sorrel's abandonment 'not only by upper-class gent but also by author, to a miserable pregnancy, a lonely childbirth and transportation'. Yet it is Ellen Weeton's Journal of a Governess, and the experience of both being a battered wife and writing about it, which shows up the literary aspect.

For Swindells is consistently scrupulous in resisting the temptation to sentimentalize the working women's accounts of their lives. She makes it emphatically clear that she is not setting out to find authentic versions of working women's experience, eschewing such questions as: 'Will the real (THE REAL) Nelly Weeton now stand forth?'. She argues that these autobiographical writings are themselves constrained by literary conventions, not least in that these women look to literature to provide a morally tenable position from which to write and to live. The most striking reason for this is that the dominant values which transform their lives into acceptable experience in writing are those which maintain (and indeed service) a culture which creates a hierarchy of texts according to who is doing the writing - their class, their gender.

The concluding chapter of the book exposes the role of editors and commentators in the power relations of the literary production process, and Swindells here makes herself accountable as a feminist and working woman to the female subjects of the historical texts she has discussed. J. J. Bagley assists Edward Hall in his chivalric rescue of Ellen Weeton - his 'sleeping princess' - no longer a drudge, a battered wife, but a fairy-tale heroine. Elizabeth Ham's editor 'liberates' her text - and, by implication, her readers - from 80,000 words of 'inconsequential gossip'. This raises the question of for whom they were producing their female subjects - for it is surely no vain speculation on Swindell's part that some of those massive excisions would have been of interest to women.

It would be a great pity if this book were read only by those with a 'professional' interest in Victorian writing, for, as its author justly claims, 'its primary concerns relate to women now, to our experiences and our perceptions of the world'. We still, in a sense, look back through a fog of stereotypical notions about Victorianism, and live with the legacy of gender attitudes and practices which were formed in that period. It is in the nineteenthcentury realist novel, which has become established as the apotheosis of a fundamentally liberal humanist genre, and more especially in the writings of working women autobiographers which have been classified as low-status texts, that Swindells locates the most visible manifestations of the class and gender relations of writing.

Much of this book is concerned with the way in which 'the art thing', and the assumptions and restrictions it involves, reflects and endorses the socio-sexual division of labour. But its argument does not end there: 'What is important now, for feminists and socialists, is not only an exposure of these veiled assumptions, but an understanding of how sexual ideology and the sexual division of labour have structured, in the past, and continue to structure, the ways in which people write and are read.'

\section{Joan Scanlon}

